\title{
BETWEEN IMPERIAL DESIGN AND COLONIAL APPROPRIATION: THE RELACIONES GEOGRÁFICAS DE INDIAS AND THEIR PINTURAS AS CARTOGRAPHIC PRACTICES IN NEW SPAIN
}

\section{ANTONIO SÁNCHEZ MARTÍNEZ AND JOSÉ PARDO-THOMÁS}

\section{Introduction}

This article suggests a new reading of the pinturas and the Relaciones Geográficas de Indias, regarding New Spain, as an example of an ambitious metropolitan project that initially followed specific imperial worldviews and interests but was ultimately redefined by the colony according to colonial worldview and interests. What was for some, the fulfillment of a project of territorial appropriation via its recognition and representation, was for others, the beginning of something new, still undecided and yet transcendent, a sort of 'invention of the New Spain'.

The pinturas of the Relaciones Geográficas are clearly a product of a stylistic hybridization led in great extent by indigenous painters. They are a result of the unique tension between the 'colonizing guidelines' of the questionnaire and the variety of local responses and situations that ended up generating outcomes from multiple and unexpected points of view, a cultural tension between predetermined regular procedure and a defiant local setting.

The iconographical corpus of the Relaciones does not comply with a dialectical analysis in terms of native/European, as demonstrated by the ongoing debate of over half a century led by authors such as Donald Robertson and Barbara Mundy, as well as Howard Cline, Serge Gruzinski, Erwin Palm and John Moffitt, up to Alessandra Russo and Gustavo Garza. ${ }^{1}$ Gruzinski already recommended that: "one has to admit that it is impossible to

\footnotetext{
1 Donald Robertson, Mexican Manuscript Painting of the Early Colonial Period. The Metropolitan Schools. (Norman: University of Oklahoma Press, 1994 [1959]); Barbara Mundy, The Mapping of New Spain: Indigenous Cartography and the Maps of the Relaciones Geográficas (Chicago: The University of Chicago Press, 1996); Howard F. Cline, "A Census of the Relaciones Geográficas of New Spain, 1579-1612", in Handbook of Middle American Indians, vol. 12, ed. Howard F. Cline (Austin: University of Texas Press, 1974), 324-369; Serge Gruzinski, "Colonial Indian Maps in Sixteenth-Century: An Essay in Mixed Cartography", Res: anthropology and aesthetics, 13 (1987): 47-61; Erwin Walter Palm, "Estilo cartográfico y tradición humanista en las Relaciones Geográficas de 1579-1581", in Heimkehr ins Exil: Schriften zu Literatur und Kunst (Köln: Bôhlau Verlag, 1992), 73-81; John F. Moffitt, "Ptolemy's Chorographia in the New World: Revelations from the Relaciones Geográficas de la Nueva España of 1579-1581", Art History, 21, 3 (1998): 367-392; Alessandra Russo, El realismo circular: tierras, espacios y paisajes de la cartografía novohispana, siglos XVI y XVII (México: UNAM, 2005); Gustavo Garza Merodio, "La pintura de la Relación geográfica de Metztitlan, 1579”, Secuencia, 66 (2006): 163-186.
} 
discern the Indian from his occidental sediment. Indigenous Mexican sources, mixed or occidental, never escape miscegenation even if in a minor extent". 2 Recently, Alessandra Russo wrote that "to say that one element is more native and another more occidental affects the interpretation in a deep and dangerous way: to consider that these 16th century images are no longer pre-Hispanic and that they are not yet Europeans is to categorically place these painters and their creations in a time-space parenthesis, in a non-place that will, in the end, result in the complete loss of a before or an after". 3 According to Russo, "it is essential to analyse these works as part of a circulation of knowledge and inventions that exceed a local scope ... by not only being inspired by artistic alternatives found in the occidental figurative materials, but also by providing information ... and offering innovative representation modalities". 4

Our purpose here is not to add to continuing discussion, but rather to examine the extraordinary set of suggestions, evocations, typological and formal relations, that the contemporary observer faces when contemplating and analysing the Relaciones.

The corpus of 'maps' or pinturas from the new-Hispanic Relaciones Geográficas is a set of seventy-five works that have survived to our day and are distributed in three different repositories. The entirety of the Relaciones, belonging to the Spanish Crown since their production in New Spain were dispersed during the 19th century. Thirty-seven pinturas are in the Nettie Lee Benson Latin American Collection of the University of Texas, Austin; ${ }^{5}$ twenty-two are held in the Archivo General de Indias, in Seville; and sixteen are found in the Royal Academy of History, in Madrid. ${ }^{6}$ According to Barbara

${ }^{2}$ Serge Gruzinski, La pensée métisse (Paris: Fayard, 1999), 197.

${ }^{3}$ A. Russo, El realismo circular, 19.

${ }^{4}$ Ibid., 21-22.

5 These pinturas are from the collection Joaquín García Icazbalceta, partially acquired by the University of Texas in 1937.

6 The contribution of the Archivo General de Indias [AGI] should be acknowledged for their work. They digitized and made available online and open access to researchers worldwide the original documents custodied in Seville. (http://pares.mcu.es; date of access 12.11.2012). More recently, the Academy of History [RAH] also made available online, and open access, excellent reproductions of the pinturas (http://bibliotecadigital.rah.es; date of access 12.11.2012). Both projects have had the support of the Spanish Governement in the form of the Cultural Ministry. The University of Texas [UTX], at the time does not seem to be willing to follow the Spanish public institutions. The authors would like to thank Angélica Morales, Haydée García-Bravo and Mauricio Sánchez-Menchero for their unsurpassable help with the consults of the originals held in Austin. Albeit the material at hand, examination of the originals is valuable for the researcher, especially when working with these paintings. It is worth mentioning that the reader may find the text and images of all the new-Hispanic Relaciones (except for the 54 from Yucatán's province) in the edition of René Acuña. See R. Acuña, Relaciones Geográficas novohispanas del siglo XVI, 10 vols. (México: UNAM Instituto de Investigaciones Antropológicas, 1982-88). Acuña preserved the grouping of the Relaciones by province: 2 relations from Guatemala; 12 from Nueva Galicia; 16 from Tlaxcala; 17 from Michoacán; 33 from Mexico; and 34 from Antequera (Oaxaca). 
Mundy, the author of the leading study on the corpus as a whole, forty-five of those pinturas were illustrated by thirty-two "presumably indigenous authors", 7 and the rest were painted by fifteen other European residents in the region of New Spain. ${ }^{8}$

Before describing the corpus and the historical circumstances of its production, it is useful to consider the ways historiography has used terms such as "map" and "painting," sometimes employed interchangeably, and the term "artist" for native authors. We would argue that by using the word 'map' for all the territorial representations contained in the Relaciones, and by designating all its authors as 'artists', we are before a case of language colonization. Using vocabulary from the colonizing culture, as if these are universal concepts, is implying that they describe a reality that is equivalent, when it is not the case. This seems to be an extension of a colonial semiotics, as suggested by Walter Mignolo in his analysis of the conflicting interactions between alternative alphabetizations of Mesoamericans and Castilians during the beginning of the settlement. ${ }^{9}$ Mignolo pointed out that the use of expressions such as 'book', 'writing' or 'scribe' were used in reference to Mesoamerican realities that, in náhuatl, would designate the object amoxtli, the action tlacuiloliztli and the person tlacuilo - objects, actions and jobs that the colonizers considered as identical to European counterparts. ${ }^{10}$ The same

\footnotetext{
${ }^{7}$ B. Mundy, The Mapping of New Spain, 30.

${ }^{8}$ Except for six cases, whose European or indigenous authorship is still debated by experts. While taking into account time passed and more recent contributions that have shed new light, it is still mandatory to follow the description and census of the whole of the documental corpus of the pinturas of the Relaciones from different works gathered between 1972 and 1976 in the 12th and 14th Handbook of Middle American Indians (ed. Howard F. Cline, 196476), essentially the chapter written by Donald Roberston and two works from J. B. Glass. See Donald Robertson, "The Pinturas (Maps) of the Relaciones Geográficas, with a Catalog", in Handbook of Middle American Indians, v. 12, ed. Howard F. Cline (Austin: University of Texas Press, 1972), 243-278; J. B. Glass, "A Survey of Native Middle American Pictorial Manuscripts", in Handbook of Middle American Indians, vol. 14, ed. Howard F. Cline (Austin: University of Texas Press, 1976), 3-80; and J. B. Glass, "A Census of Native Middle American Pictorial Manuscripts", in Handbook of Middle American Indians, v. 14, ed. Howard F. Cline (Austin: University of Texas Press, 1976), 81-252. Two more general chapters by H. F. Cline may also be useful since they present a census of the Relaciones and annotated bibliography on them. See Howard F. Cline, "A Census of the Relaciones Geográficas of New Spain"; and H. F. Cline, "The Relaciones Geográficas of Spain, New Spain, and the Spanish Indies: An Annotated Bibliography", in Handbook of Middle American Indians, vol. 12, part 2, ed. Howard F. Cline (Austin: University of Texas Press, 1974), 370395.

9 Walter D. Mignolo, "Colonial Situations, Geographical Discourses ad Territorial Representations. Toward a Diatopical Understanding of Colonial Semiosis”, Dispositio, 14 (1989): 93-140.

${ }^{10}$ Mignolo returned to colonial semiotics. W. D. Mignolo, "Signs and Their Transmission: The Question of the Book in the New World", in Writing without Words. Alternative Literacies in Mesoamerica \& the Andes, eds. E. Hill Boone and W. D. Mignolo (Durham: Duke University Press, 1994), 220-270, 239-241, 265. Mignolo developed the differences in worldview behind the concepts of tlacuilo as "scribe" and amoxtli as "book" between
} 
occurs with the classification of 'maps', applied to certain pinturas, and 'artist' applied to a native author. Henceforth in this essay the word pintura will be used for all images in the corpus, and either the word 'painter' or tlacuiloque for European or native authors respectively. ${ }^{11}$

Reflecting on language colonization, Mignolo also uses the concept of misunderstanding. ${ }^{12}$ According to his account, the agenda to impose occidental alphabetization used by colonizers and evangelizers in Mesoamerica stirred and further fuelled many misinterpretations between both cultures. Granted, this happened with many other aspects of the so-called 'encounters between Europeans and other people', ${ }^{13}$ in this case, however, we believe this idea may be of valuable assistance to the understanding of the production of the pinturas of the Relaciones.

The misunderstandings created during the cultural confrontation had consequences on the pinturas, and their native authors, that are of critical importance to appreciate the dependency and the subordination that the colony created amidst the native population. The same misunderstandings also led to

Mesoamerican and European cultures, in the frame of his characterization of a process of colonisation of language. W. D. Mignolo, The Darker Side of the Renaissance. Literacy, Territoriality, \& Colonization (Ann Arbor: The University of Michigan Press, 1995), 29-122.

${ }^{11}$ The word náhuatl tlacuilo (part of the verb icuiloa, when it is not compounded) and its plural tlacuiloque were used in pre-Hispanic society to designate members of the community dedicated to a "honourable profession", whose apprenticeship was constrained to members of the elite and that integrated the functions that in the colonisers society was held by scribes and painters, but not merely restricted to that. They were experts in a set of specific techniques that would give them access to a body of special knowledge on the collective memory of their society, its genealogy, its rituals, etc. The tlaquiloque maintained tight bonds with their communities of origin in the first years in the colony through the Christianised youth whose teachings assured the tlaquiloque would incorporate European artistic techniques and visual imagery. Their work was largely exploited during the first century of colonisation directed into Christianising projects of the religious orders: painting murals, prepare works and images for Christian religious indoctrination, etc. See Marc Thouvenot, "Imágenes y escritura entre los nahuas del inicio del siglo XVI”, Estudios de Cultura Náhuatl, 41 (2010): 167-191; Jeanette F. Peterson, "The Florentine Codex Imagery and the Colonial Tlacuilo", in The Work of Bernardino de Sahagún, Pioneer Ethnographer of Sixteenth-Century Aztec Mexico, eds. J. Jorge Klor de Alva, H. B. Nicholson, Eloise Quiñones Keber, (Albany, NY: The University at Albany State University of New York, 1988), 199-210; J. F. Peterson, "Image/Texts in Sixteenth-Century Mexican Murals (A Devil in the Details)", in Sources and Methods for the Study of Postconquest Mesoamerican Ethnohistory, eds. James Lockhart, Lisa Sousa \& Stephanie Wood (Austin: University of Texas Press, 2007), 1-21; Elizabeth H. Boone, "Writing and Recording Knowledge", in Writing Without Words: Alternative Literacies in Mesoamerica and the Andes, eds. Elizabeth H. Boone and Walter Mignolo, (Durham: Duke University Press, 1994), 3-26; James Lockhart, The Nahuas after the Conquest (Stanford: Stanford University Press, 1992).

${ }^{12}$ W. D. Mignolo, "Signs and Their Transmission", 222-227.

${ }^{13}$ Stuart B. Schwartz, ed., Implicit understanding: observing, reporting, and reflecting on the encounters between Europeans and other peoples in the early modern era (Cambridge: Cambridge University Press, 1994). 
moments of contestation, resistance and appropriation, and such is the space that cultures that are in the process of being colonized need to have in order to be heard and to leave a mark of their own memories and cultural ancestry. The interpretation of the Instrucción of 1577, that produced the pinturas, is a paradigmatic example, as we will show in the analysis of the different contexts of creation of the Relaciones in Madrid, and the contexts of production in New Spain.

\section{A Metropolitan Project for a Chorography of the Indies}

Unlike the Portuguese overseas empire, mostly founded on nautical supremacy, the Spanish Empire had to face a territorial occupation of its possessions and the practice of territorial sovereignty and official control of space. The two monarchies developed distinct forms of domination, and employed different approaches to materialize each of their colonial possessions. ${ }^{14}$ While Portugal focused its colonial enterprise towards the establishment of safe and lucrative commercial routes, Spain directed its 'conquistador' skills towards already populated areas in the American continent. To the Spanish monarchy, the representation of the occupied territories was as crucial as the occupation itself in the construction of its sovereignty. It is in this context and following this logic that the Relaciones were created, from the very obsession of the Spanish court to normalize all knowledge concerning the Indies, including the physical space, the territory and, with it, the American natural world.

In the broad context of Iberian expansion, as viewed from the metropolis, there seems little doubt that the Relaciones and the pinturas should be the culmination of the last phase of development of a colonial cosmography, a step of consolidation that would lead to territorial confirmation. Once the first explorations and conquests were over, the time had come to consolidate the discoveries with specific plans of action. In order to achieve this, the cosmographic artefacts idealized by the Crown and the Council of the Indies should now reflect greater localism and materialization. Hence the pinturas were conceived as a representational system based in a chorographic study of Indian nature, an ambitious metropolitan project for geographical colonization. This was thought in the context of an ample imperial worldview that was in turn constructed in recognition, representation and, ultimately, territorial appropriation. According to this mind-set, chorographic representation was the more promising and effective means to fulfil localized sovereignty. The pinturas of the Relaciones were for the geography of the New World, what the cartographical Padrón Real was for

\footnotetext{
${ }^{14}$ Patricia Seed, Ceremonies of Possession in Europe's Conquest of the New World, 14921640 (Cambridge: Cambridge University Press, 1995); Juan Pimentel, "The Iberian Vision: Science and Empire in the Framework of a Universal Monarchy, 1500-1800", Osiris, 15 (2001): 17-30.
} 
hydrography in the Casa de la Contratación in Seville. Thus the pinturas of the Relaciones were a cognitive mechanism created to recognize, organize and manage new information. ${ }^{15}$

The guidelines for this project stemmed from the aspiration to make visible the Crown's sovereignty in reference to a cosmographic polity that depended on cartographic representation of colonial possessions and the construction of an imaginary control and authority over distant lands. Only thus is it possible to understand the manner in which the pinturas were designed in Castille to collect an exhaustive knowledge of the new-Hispanic territories. The chorographic Relaciones of New Spain had the purpose to assist with an effective conquest of the land.

The Relaciones were the last link in a large and complex chain of geopolitical events that began in 1492. The pinturas were supposed to be the finished product of the American cartography, the definitive evidence of regions already explored by the means of local images of specific places. However, the misunderstandings that we have made reference to, as well as the complex reality of the viceroyalty and the distance between different coasts of the ocean transformed the initial project into a different product.

The Relaciones had a background dating back to the first decades of the 16th century. As early as the 1520 s the Council of the Indies asked for "descriptions" of the new lands. Manuscripts attributed to the cosmographer of the Council of the Indies, Alonso de Santa Cruz (1505-67), appear to be the antecedents of the Relaciones, particularly his Parecer sobre descubrimientos en las Indias, though it was left undated and unsigned in a chest full of his manuscripts. The similarity of this manuscript to the later instructions of Juan de Ovando, President of the Council of the Indies, suggests that Santa Cruz began the first official compilation of data from the American world. ${ }^{16}$

Similarly, the Epítome de la conquista del Nuevo Reino de Granada, whose author may again be Santa Cruz, is considered as a precedent of the questionnaire cartography led by Ovando. ${ }^{17}$ The Epítome is a short document produced around mid-century and whose provenance is the 'arca' of Santa

15 Antonio Sánchez, La Espada, la Cruz y el Padrón: soberanía, fe y representación cartográfica en el mundo ibérico bajo la Monarquía Hispánica, 1503-1598 (Madrid: CSIC, 2013).

16 Jesús Bustamante, "El conocimiento como necesidad de Estado: las encuestas oficiales sobre Nueva España durante el reinado de Carlos V", Revista de Indias, 60, 218 (2000): 3355, 52; Antonio Barrera-Osorio, "Nature and Empire in the New World" (Ph.D. diss., University of California, 1999), 286.

${ }^{17}$ Jiménez de la Espada attributed authorship to the quixotic figure of Gonzalo Jiménez de Quesada, explorer and Spanish conquistador who made heroic achievements in present day Colombia. Marcos Jiménez de la Espada, Relaciones Geográficas de Indias. 4 vols. (Madrid: Ministerio de Fomento, Tipografía de Manuel G. Hernández, 1881-1897). 
Cruz, a chest where most of his cartographic works were kept. The enclosed description of an itinerary through the interior of the country offers yet another particular vision of the American world. ${ }^{18}$

Juan de Ovando presided over the titanic metropolitan project to satisfy Philip II's vast aspirations for the Indies. In 1569, two years after Santa Cruz's death, he published the Copulata de Leyes de Indias, also known as the "Ovandine Codex", and in 1571 the Ordenanzas of the Council of the Indies. He was replaced by López de Velasco, who inherited Santa Cruz's manuscripts and his office of Cosmographer for the council. In 1574 Velasco produced the Geographía y descripción de las Indias. These works anticipated much of the information in the Instrución y memoria de las Relaciones que se han de hacer para la descripción de las Indias, and the Cuestionaries, both printed in $1577 .{ }^{19}$

The model of the questionnaire was thus born from the 'Ovandine codex', a type of instructions borrowed from Santa Cruz's Parecer, and was to become the new procedure adopted by the Crown to acquire accurate and detailed information from the American geographical reality. ${ }^{20}$ The questionnaires were an empirical method adopted to consolidate, sets of instructions with a list of various questions and requirements sent by the Council of Indies to the viceroys. These listings laid out in minute detail the procedures of observation and collection of the new information. ${ }^{21}$ Beyond the physical delimitation of the terrain, these questionnaires also represented a form of 'spatial control' based in the establishment of areas of political, cultural and economic influence that would allow claiming dominion over conflicting interests.

This form of control was organized according to the administrative distribution of the territory in the bureaucratic systems of the Crown. These systems comprised cabildos, corregimientos, gobernaciones, audiencias and virreinatos; the secular support to each sector of the exploitation and development of the natural resources; the distribution of the native population in encomiendas, reducciones, doctrinas and misiones; and the gradual

\footnotetext{
${ }^{18}$ Carmen Millán de Benavides, Epítome de la conquista del Nuevo Reino de Granada: la cosmografía española del siglo XVI y el conocimiento por cuestionario (Bogotá: Pontifica Universidad Javeriana and Instituto de Estudios Sociales y Culturales Pensar, 2001).

${ }^{19}$ W. D. Mignolo, The Darker Side of the Renaissance, 283

${ }^{20}$ Clinton R. Edwards, "Mapping by Questionnaire: an Early Spanish Attempt to Determine New World Geographical Positions”, Imago Mundi, 23 (1969): 17-28.

21 Arndt Brendecke, Imperium und Empirie. Funktionen des Wissens in der Spanischen Kolonialherrschaft (Köln, Böhlau Verlag, 2009).
} 
implementation of the urban system. ${ }^{22}$ The answers to the questionnaires were to become the famous Relaciones.

The first questionnaire, which dates from 1569, was revised around the seventies, and finally reduced to 50 questions in $1577 .{ }^{23}$ In the same year that the final questionnaire was published, the first descriptions of the American territory began to arrive to the metropolis brought back by the colonial administrators. The scientific overseer of the enterprise was the aforementioned Chief Cosmographer-Chronicler of the Indies, Juan López de Velasco. $^{24}$

López de Velasco was, in practice, the promoter of the production of maps by questionnaire. ${ }^{25}$ López de Velasco developed a series of activities that would facilitate the access to American lands from the metropolis; he reorganized and systematized the legislation applicable in the Indies; legislated rules for settlement; requested district reports and information on native population, usually expanded with geographic data; compiled the Indies regional geography based on these reports; and developed a geographic and ethnographic questionnaire that was sent to all audiencias of the new continent, which reached its final design in $1577 .{ }^{26}$ All these efforts were part of an ostentatious and somewhat utopian imperial project developed by a cabinet cosmographer, a courtier who never travelled to America and who accomplished his duties mediated by these relations and lists, something that Karl Butzer has called 'government geography'. ${ }^{27}$

The role of López de Velasco's contribution, in synthetizing into maps and reports the empirical information arriving from the Indies, brought to light his ability to gather and collect data from distant lands, then compile this information, that was in many cases dispersed, and reconfigure it in a clear and concise language producing, from a distance, his own interpretation of the

\footnotetext{
${ }^{22}$ Pilar Ponce Leiva, "Los cuestionarios oficiales: ¿un sistema de control de espacio?", in Cuestionarios para la formación de las Relaciones Geográficas de Indias: siglos XVI-XIX, ed. Francisco de Solano (Madrid: CSIC, 1988), xxix-xxxv, xxxii-xxxiii.

${ }^{23}$ This new, more refined and definitive questionnaire was elaborated with greater degree of maturity than the previous ones and, consequently, gave place to a good number of documents from New Spain. Francisco de Solano ed., Cuestionarios para la formación de las Relaciones Geográficas de Indias: siglos XVI-XIX (Madrid: CSIC, 1988), 79-86.

${ }^{24}$ Stafford Poole, Juan de Ovando: Governing the Spanish Empire in the Reign of Philip II (Norman: University of Oklahoma Press, 2004); Maria M. Portuondo, Secret Science: Spanish Cosmography and the New World (Chicago: The University of Chicago Press, 2009), 141171.

${ }^{25}$ C. R. Edwards, "Mapping by Questionnaire".

${ }^{26}$ Karl W. Butzer, "From Columbus to Acosta: Science, Geography, and the New World", Annals of the Association of American Geographers, 82, 3 (1992): 543-565, 556.

${ }^{27}$ Ibid., 554. J. P. Berthe, "Juan López de Velasco (ca. 1530-1598), Cronista y Cosmógrafo Mayor del Consejo de Indias: su personalidad y su obra geográfica", Relaciones 19, 75 (1998): 142-172.
} 
Indies. $^{28}$ This was how López de Velasco acted in accordance with the demands of the Council of Indies and Phillip II's cosmographic and globalizing plan. The expected outcome of this project, for the Chief Cosmographer-Chronicler, and in last instance for the monarch, was a complete and detailed chorography of colonial possessions.

\section{A Ptolemaic chorography for New Spain}

According to the guidelines in Ptolemy's Geographia, the word chorographia stands for a description of a particular region, a drawing of a specific and well defined territory. The chorographic maps of the Renaissance are more committed to a pictorial and scientific tradition of landscape representation than to geometrical proportions. They embody both pictorial and scientific representation in the way of a figurative map. The chorographic images would be the setting in which to describe the particularities of a place where past and present history are framed by local history.

The pinturas of the Relaciones were intended to address a specific cartographic model associated with the illustration of the particular, a qualitative fresco in its details. World maps had the virtue of demonstrating which regions of the globe were under Spanish jurisdiction, in turn, chorographic maps were the images requested by the King in order to gather a concrete knowledge of the region of the Indies. This specificity also answered more precise needs, such as claims on land invasion, property limits, water usufruct, delimitation of pathways, proper placement of villages and cities, acknowledgement of provinces, and the fixation of civilian and religious jurisdiction. $^{29}$ Far from abstraction or geometric conformity, a pintura demanded that the 'artista' was able to recreate a vivid portrait of a localized terrestrial physiognomy. ${ }^{30}$

Both the Council of Indies and Ovando followed Ptolemaic cartography in the reform of the Indian cosmography. Castilian bureaucracy was rooted in a traditional visual model for the representation of its overseas possessions. Even if the Ptolemaic world only extended to the Islas Afortunadas, Ptolemy's guidelines were now used to represent the whole of the oikoumene to include New Spain. The Council of Indies called for chorographic maps and particular representations in order to possess a more concrete knowledge of Indian lands.

The Spanish monarchy thus accomplished the Indian enterprise using guidelines from the Geographia of Ptolemy in world maps as well as in

\footnotetext{
${ }^{28}$ R. Beltrán y Rózpide, “América en tiempos de Felipe II, según el cosmógrafo-cronista Juan López de Velasco”, Publicaciones de la Real Sociedad Geográfica, 48, (1927): 1-48.

${ }^{29}$ Francisco Takaki et. al., Cartografía histórica del encuentro de dos mundos (México: Instituto Nacional de Estadística, Geografía e Informática, 1992), 150-151.

${ }^{30}$ J. F. Moffitt, "Ptolemy's Chorographia in the New World", 381-382.
} 
regional maps, from the map by Juan de la Cosa (1500) up to the pinturas of the Relaciones. The Crown developed its own cosmographic project according to the Ptolemaic systems of representation, as they were recovered by humanist geography in the decades before $1492 .{ }^{31}$ The ideas of the Greek geographer were, from beginning to end, the foundation of the colonial cartographic creation and his distinction between cosmography and chorography determined the Iberian cartography of the Discoveries.

In the final decades of the 16th century, regional cartography was responsible for the production of precise information on the colonies. The theoretical teachings inherited from Ptolemy were modulated in practice with the compilation of exact and verified data used to represent the inhabited world, from the universal to the particular. Painters, tlacuiloque, cosmographers, officers and even improvised artists were to ultimately fulfil the principles of Ptolemaic geography, notwithstanding their diverse nature, as we will show further on. In this sense, the maps were not only the first step in the appropriation of the territory as also the definitive one. ${ }^{32}$ The chorographic pinturas incorporated on the narrated chronicles of the New World were to constitute the final project of appropriation of the territory. They were nevertheless converted into a completely autonomous sign of self-affirmation.

\section{The pinturas as hybrid cartographic representations}

Once the project of the Relaciones was launched in New Spain territory, the pinturas assumed a rich and complexly woven ideology, marked by a hybridization of cultures that sanctions us to compare to it to the processes of hybridization that characterized the new-Hispanic chorographic representation as 'hybrid cartography'. ${ }^{33}$ The indigenous and colonial cartography of the old Mesoamerica was, in the final quarter of the 16th century, a hybrid cartographic representation where we may find both contradictions and similitudes between local and universal knowledge, European and Native culture, imperial and colonial ideology, native and imported art. The landscape fragments and the figures of characters following western canons on the one hand, and the decorative details of pre-Hispanic inspiration on the other, conflate the same pintura into a new genre characterized by a double language and expression, an admirable mix of both artistic and scientific ingredients. On an iconographic level the hybridization is even more noticeable. In the

\footnotetext{
31 A. Sánchez, "Cosmografía y humanismo en la España del siglo XVI: la Geographia de Ptolomeo y la imagen de América", Scripta Nova. Revista Electrónica de Geografía y Ciencias Sociales, XV, 354 (2011). [Online] http://www.ub.es/geocrit/sn/sn 354.htm.

32 John Brian Harley, "Rereading the Maps of the Columbian Encounter", Annals of the Association of American Geographers, 82, 3 (1992): 522-536.

33 Amara L. Solari, "The Relación Geográfica Map of Tabasco: Hybrid Cartography and Integrative Knowledge Systems in Sixtenth-Century New Spain”, Terrae Incognitae, 40 (2009): 38-58.
} 
iconographic symbols of the pinturas it is possible to distinguish traits that are prior to the conquest, traits from the subsequent period and also a mix of both. ${ }^{34}$ Nowadays, the pinturas may be exposed as both carriers of the transformation of the geographic territory under the new regimen and as products of the interaction between European and pre-Hispanic cultures.

The chorographic representations of new-Hispanic regions form heterogeneous compounds from two very distinct worlds whether they were produced by Castilian painters or by tlacuiloque, members of the native elite that, even if most are anonymous or unknown to us, would have had access to certain levels of European education, particularly through the contact with the evangelizers. Even so, the pinturas created a certain agreement between colonizers and colonized as truthful representations of the land. Many of these maps were created by survivors of pre-Hispanic cultures and adopted by the colonial administration. The arbitrariness of the hands that created these descriptions produced a very rich juxtaposition of styles. The receivers of such lively images of American nature and civilization weren't the Amerindian chiefs, but renaissance courtiers and princes. In the pinturas, the supposed objectivity of representation in the process of imitating reality is also a mirror of the underlying values that dominated the production of these hybrid artefacts. In effect, they were an intersection of cultures where the art of one brings to life the savagery of the other. The ideological connotations exceed the mathematical and geometrical data of the representation, behind the desired precision and exactitude of the image there is a non-causal cumulus of subjectivity, intentions and ideas that somehow legitimate the framework where these maps were drawn.

The pinturas registered the ideal geometry of the native conception of the settlement, the landscape and the territory. Far from being a passive object, these images act as agents, as its representation offers visual explanation of the European view over the Mesoamerican villages in particular and the New World in general. As most chorographic representations made in the Indies, the pinturas are active 'maps', living documentation of the point of origin from where the natural and the human world propagated, most of them drawn from a native source, but destined for European eyes. The depicted fauna, flora and, sometimes, humans, offer a dynamic frame around the portrayal of daily quotidian. The pinturas speak both actively and passively, just like the texts where they are attached.

In short, the New Spain chorography in the form of the pinturas was supposed to have made available to the Crown the local knowledge demanded by the questionnaires but, instead, things didn't work out in the colonies as

\footnotetext{
${ }^{34}$ J. W. Bailey, "Map of Texúpa (Oaxaca, 1579): A Study of Form and Meaning”, The Art Bulletin, 54, 4 (1972): 452-472.
} 
was expected in the metropolis. What were the impediments and how did the transformation of the project happen? Where was the 'misunderstanding', if in fact this is what it was? In the context of production of the pinturas, the colonial reality imposed a substantial change in the original idea. The distant reality somehow changed the Native American policy such as it had been designed in the imperial plan of Phillip II.

\section{Contexts of production: colonial interpretations of the metropolitan project}

Once the control mechanism was launched from the distant metropolis over the territory, in each case - and there are hundreds - the product was transformed into something original and atypical, the result of complex negotiation between the numerous actors involved (authorities, evangelizers, settlers, interpreters, native elites, other elements of the communities, etc.) and the exceptionally varied geographic realities of each region into which the new-Hispanic territory was being divided. The production of the pinturas that would occasionally accompany the written document with the answers to the questionnaire is a clear example of the ample margin left for negotiation.

An instruction that few observed, was that the first ten questions were designed especially for the "Spanish villages", whereas the "Indian villages" were to answer questions eleven to fifteen. And it is question number ten, precisely, that records the requirement to accompany the description with "the place where said settlements are ... with their traces", which meant that a plan to Spanish settlements was sought after. The following question, number eleven, stated that "it should be stated how much the Indian villages are distant from the villages where they belong to". The final questions, from number thirty-eight on, were designed specifically for the coastal populations and included, in questions number forty-two and forty-seven, the order to depict by "figura y traza" the ports and bays, as well as the "figura en pintura" of isles and coastal islets. The clear purpose is, in this case, to improve the construction of a precise map, a proper portulan in detail of the coastline of the Indies, a fundamental element for the exercise of colonial power whose agents and interests were depending, evidently, of the maritime routes that united metropolis and colonies. ${ }^{35}$

\footnotetext{
${ }^{35}$ Few were the 'maps' from the Relaciones that contributed to efficiently undertake this project defined in the metropolis. Amongst them were, without doubt, the relation of Veracruz, Zapotitlán and three others elaborated by the Italian sailor Francisco Stroza Gali (Coatzocoalcos, Tehuantepec y Tlacotlalpa). The relation made by Diosdado Treviño, a priest in Los Peñoles, was, in a way, also a part of this group, but no other of the existing documents reached the expectations.
} 
A strict interpretation of question ten, i.e. to draw the Spanish village and its jurisdictional territory, following the established criteria, wouldn't have led the local authorities to appoint a tlacuilo to the production of pinturas of so many native communities, and much less so, to use ancient pinturas kept by them. Donald Robertson has already demonstrated how some pinturas added to the Relaciones were produced much earlier and that, in fact, the description of the territories included in the answer of the questionnaire is based on the pintura instead of merely illustrating it. ${ }^{36}$ This shows how the results that some of the pinturas offered couldn't have been more different from the desired intentions of the chorographic project of López de Velasco. Nevertheless, these outcomes assisted the native communities in different ends, namely to promote and legitimize their own production of "pinturas antiguas", that only a few decades earlier would have been systematically destroyed by conquistadores or clerics.

In other words, the Instrucción was designed to create a Spanish imperial chorography, but the implementation of the project was left in the hands of local colonial administrators who, in many cases, engaged the collaboration of the native elites. This development turned out to create something very different that, in a way, contributed to the 'invention of a New Spain', as we suggest in this paper, following the concept proposed by Edmundo O'Gorman. ${ }^{37}$

Without denying the weight of the Ptolemaic chorographic tradition analyzed in the earlier section and that was also discussed by authors Erwin Palm and John Moffitt, the pinturas of the Relaciones seem to have somehow transformed into the product of an autochthonous gesture of affirmation by both Spanish and new-Hispanic creoles. ${ }^{38}$ The native communities, who, in the end, are formally and technically responsible for two thirds of the corpus that exists today, took the instructions and transformed them into their own profit, or, to use a Spanish idiomatic expression, hicieron de su capa un sayo.

\section{The pinturas of European painters}

Firstly, let us take into account the pinturas that have a clear European authorship. Studies have shown that European styles of representation found in the pinturas of the Relaciones and also evident in surveyor maps, that were

\footnotetext{
${ }^{36}$ D. Robertson "The Pinturas (Maps) of the Relaciones Geográficas"; A. Sánchez, "La representación cartográfica en el siglo de oro de la cosmografía española: categorías epistémicas en la fabricación de modelos visuales" (Ph.D. diss., Universidad Autónoma de Madrid, 2010), 454.

${ }^{37}$ Edmundo O'Gorman, La invención de América (México: FCE, 1958).

${ }^{38}$ E. W. Palm, "Estilo cartográfico y tradición humanista"; and J. F. Moffitt, "Ptolemy's Chorographia in the New World".
} 
common in medieval Europe and had roots back to imperial Rome. ${ }^{39}$ In the 1950s, scholars had focused on the remnants of indigenous styles and their progressive disappearing or shifting as consequences of acculturation. In 1992 Palm selected pinturas - for him they are maps -, of the Relaciones that "combine the plan of a city and a map of an area, using different scales to reproduce the outskirts and the city" 40 and centred his analysis on pinturas such as Coatepec and Jalapa. To establish the European styles that had influenced those pinturas, Palm almost immediately discarded the cartographic sophistication that European cities' representation achieved, according to him, with Sebastian Münster and his printed production between 1528 and 1538. In exchange, he assured that surveyor maps found preserved in a 6th century codex, edited by Carl Olof Thulin in 1913, could "constitute the model for the biproportional plans". 41

In order to explain the different routes of transmission from Roman surveyors to 16th century New Spain, this author argued that the 6th century treatise was part of the didactic literature transmitted during the Middle Ages that had large circulation in the end of the 15th and beginnings of the 16th century. This circulation pattern would comply to the humanist agenda "of the daily life of Romans" 42 connecting it to the publication of De agrorum conditionibus et constitutionibus limitum (París, 1554), attributed to Gallandus and Turnebus, both interested in discussions of philology (Latin vocabulary with new terms) and juridical-practical (Roman law applied to practical quotidian questions such as fixation of land limits). These authors faithfully reproduce the illustrations of the 6th century codex. A copy from the library of Diego Hurtado de Mendoza ended up, as is well known, in the hands of Phillip II, and was part of the original core of the Library of the El Escorial. From this follows the conclusion that "this was the first edition of the surveyors that would impose a Roman style to the maps of the Relaciones". ${ }^{43}$ Similarly, the work of Johannes Metellus Sequanus, includes a posthumous cartography of America, produced between 1545 and 1555 . He was the secretary of Antonio Agustín, a Spanish savant close to the Brussels' Court of the future king Phillip II, and in previous years had worked as a librarian in the Vatican Library, something that would have put him in contact with the 6th century codices that included such Roman surveyor images.

\footnotetext{
39 G. Garza Merodio, "La pintura de la Relación geográfica de Metztitlan"; Federico Fernández Christlieb et. al. "El altepetl de Metztitlan y su señorío colonial temprano", in Territorialidad y paisaje en el altepetl del siglo XVI, coords. F. Fernández Christlieb and Ángel Julián García Zambrano (México: FCE-Instituto de Geografía UNAM, 2006), 479-530; Martín Olmedo Muñoz, "La visión del mundo agustino en Meztitlán”, Anales del Instituto de Investigaciones Estéticas, 94 (2009): 27-58.

${ }^{40}$ E. W. Palm, "Estilo cartográfico y tradición humanista", 74.

${ }^{41}$ Ibid., 76.

${ }^{42}$ Ibid, 74-77.

${ }^{43}$ Ibid., 80.
} 
In turn, John F. Moffitt was also interested in the "few" pinturas of the Relaciones that were categorized as the compound type, a terminology used by earlier scholars ${ }^{44}$ meaning those images that combine the plan of a city with a panoramic of the surrounding area. Insisting on the presence of Ptolemaic chorography in the cosmographic and cartographic projects of the Spanish monarchy for the Indies, Moffitt qualified these as "mostly ignored colonial relics." ${ }^{45}$ Thus the pinturas of the Relaciones were like fossils that perpetuated something that "in pre-medieval times, both European and Americans had in common in their map-making techniques. ${ }^{46}$ Moffitt also began his analysis by the Coatepec pintura and with the plan of Jalapa, which he considered to follow the commonplace of the artisanal medieval practices regarding conventions of spatial representation. ${ }^{47}$ Moffitt concludes that there is nihil novo sub sole (nothing new under the sun) in the pinturas of the Relaciones, regarding spatial and territorial representation techniques; they were firmly established in classical antiquity and spread throughout the medieval period. ${ }^{48}$

Barbara Mundy reached the same conclusions when she recalled that at least one edition of Ptolemy existed in the Franciscan Library in Tlatelolco, when attempting to explain the apparent familiarity that some authors of the pinturas of the Relaciones seem to have with classical chorographic maps. ${ }^{49}$ Mundy was thinking of the Meztitlan pintura, made by Gabriel de Chávez, and took it as an outstanding example of a "chorographic view", while admitting to its exceptional character within the corpus of the Relaciones. Chávez also detected the same familiarity with the printed material in two pinturas from the fragments of Ixcatlán, Oaxaca under the orders of Corregidor Gonzalo Velázquez de Lara. ${ }^{50}$

\footnotetext{
44 D. Robertson, "The Pinturas (Maps) of the Relaciones Geográficas"; H. F. Cline, "A Census of the Relaciones Geográficas of New Spain"; J. B. Glass, "A Survey of Native Middle American Pictorial Manuscripts".

45 J. F. Moffitt, "Ptolemy's Chorographia in the New World".

${ }^{46}$ Ibid., 367-368.

47 Ibid., 371. On Coatepec, see Tomás Jalpa Flores, "La construcción de los nuevos asentamientos en el ámbito rural: el caso de las cabeceras de la provincia de Chalco durante los siglos XVI y XVII", Estudios de historia novohispana, 39 (2008): 17-42; and T. Jalpa Flores, La sociedad indígena en la región de Chalco durante los siglos XVI y XVII (México: INAH, 2009), where the author relates the three pinturas of the Relaciones mentioned on the Coatepec fragment, the only references to altepetl de Chalco. On the other hand, the work of Jalpa contains many more information and it is an excellent example of microanalysis of an indigenous community after the conquest.

${ }^{48}$ J. F. Moffitt, "Ptolemy's Chorographia in the New World", 385.

${ }^{49}$ Miguel Mathes, Santa Cruz de Tlatelolco, la primera biblioteca académica de las Américas (México: Secretaría de Relaciones Exteriores, 1982), 63.

${ }^{50}$ Judging by the analysis of Delgado López, the cases of the pinturas of both Acapiztla and Cimapan do not seem very different. Enrique Delgado López, "Paisaje y cartografía en la Nueva España. Análisis de dos mapas que acompañan al corpus de las Relaciones Geográficas (1577-1583)”, Estudios de historia novohispana, 28 (2003): 77-102.
} 
Likewise, Georgina Endfield insisted that the practice of the "rural mapping" was solidly rooted in 16th century Spain, where maps were used in quarrels about land feuds, water access, and contestation of property donations. Endfield's conclusions agree with the common interpretative framework in the years preceding the publication of her work: "As a result of his reciprocal communication through mapped images, Spanish and indigenous map making were closely related in their evolution in the early colonial period". ${ }^{51}$ Interestingly though, Endfield's study concentrates almost exclusively on the pinturas coming from the Michoacán district, a provenance that, as the author herself notes, didn't produce many pinturas for the Relaciones. Moreover, the few existing works from Michoacán with their rough manufacture and almost total European style, contrast with the pinturas made by natives in that same area and timeframe. Even more noteworthy, from our perspective, is that Endfield also had pointed out the extreme convenience in contrasting the well-known corpus of the pinturas of the Relaciones with another one, by then much less known by the scholars of New Spain cartography of the first colonial periods: the "maps" produced in the context of land feud or donations, preserved in the documents of the section Tierras in the Archivo General de la Nación. ${ }^{52}$

This challenge was taken by Alessandra Russo and her study was in turn essential to the development of our argument, she suggested an analysis of the pinturas of the Relaciones as a genuine new-Hispanic production, and not to follow rigid and unique frameworks for the analysis the degree of similitude, resemblance or genealogic affiliation departing from European cartography, since this detailed knowledge is useful for a comprehensive knowledge of the singularity of the pinturas. ${ }^{53}$ This singularity should definitely not be defined, in our understanding, in terms of a fossilization of medieval forms and traits, be they of European or pre-Hispanic origin.

\footnotetext{
${ }^{51}$ Georgina H. Endfield, "Pinturas, Land and Lawsuits: Maps in Colonial Mexican Legal Documents", Imago Mundi, 53 (2001): 7-27, 9, 13-14. There is also a familiarity between the pinturas of the Relaciones and the so-called 'mapas de términos' from Castille in 15th and 16th centuries. The mapas de términos were drawings or plans used by local authorities in Castille for final decisions of feuds on territorial rights. These representations could well be one of the first examples of juridical cartography in Europe. These local maps represented Castilian requirements and properties about which no few juridical disputes were made. See A. Sánchez, "La representación cartográfica en el siglo de oro de la cosmografía española", 427.

${ }^{52}$ Mercedes Montes de Oca, et. al., Cartografía de tradición hispano indígena I. Mapas de mercedes de tierra, siglos XVI y XVII (México: UNAM - Archivo General de la Nación, 2003). See available maps in the repositories of the same archive (http://www.agn.gob.mx/mapilu/index1.htm) and in the Biblioteca Digital Mexicana (http://bdmx.mx/detalle.php?id_cod=44). In 2011, UNESCO acknowledged 300 of these newHispanic maps from the AGN as World Heritage. Cf. The exhibition La cosmovisión indígena en los mapas novohispanos organized by AGN to celebrate this honour, opened to the public in the Sala de Banderas of the Archive between $28^{\text {th }}$ July 2011, until $2^{\text {nd }}$ March 2012.

${ }^{53}$ A. Russo, El realismo circular.
} 


\section{The pinturas of the tlacuiloque}

In the case of native authors, anonymity is the general tone: we don't know who exactly the authors of the pinturas were. There are only three cases where the text offers the name of the author of the pintura and all three are from the district of Mexicaltzingo. The pintura of Iztapalapa was painted by Martín Cano, as is described by the main author of the text, the settlement's priest, Francisco de Loya. The name in náhuatl means "water close to the stone" and Cano uses a distinct toponymic glyph for it, drawing it under the church, alongside a path that is depicted with a pre-Hispanic technique: two parallel lines with human footprints between them. The drawing of the church and the tracing of the path are both similar to the second such pintura in the Relation of Culhuacan, painted by the tlacuilo Pedro de San Agustín, identified by the authors of the text, the Corregidor Gonzalo Gallegos and the friar Juan Núñez. Pedro de San Agustín went beyond his drawing and stamped his name in the back of the pintura, the only case in the whole of the corpus. The text in the third case, a pintura depicting the 'cabecera del partido' Mexicaltzingo, informs us that it was "hecha por Domingo Bonifacio, indio pintor". 54

Even if he was not specifically considering the pinturas of the Relaciones, George Kubler described the progressive extinction of preHispanic traces in the works of native artists, with five different criteria. ${ }^{55}$ The simultaneous presence of the drawing of a church near a toponymic glyph, as in the aforementioned case, is a solid example of the juxtaposition of preHispanic and colonial forms in codices and pinturas, of Kubler's first criterion. The second criterion, the convergence of similar unconnected forms between traditions, is visible in those pinturas of the Relaciones such as the Huaxtépec, where right next to water lines drawn in the pre-Hispanic style we find buildings with brick walls depicted with a distinct European style. The third criterion proposed by Kubler is of the 'explant' of a feature of native tradition developing in the colonial period, as happens with some toponymic glyphs in the pinturas of Tehuantepec and Macuilsuchil, to which we will return. The fourth criterion is of a transplant of an isolated but significant trait from native tradition that is incorporated in the colonial scheme without any major change. The clear example would be the drawing of the barefoot prints over the path, a trait whose presence we have identified in two of the pinturas

\footnotetext{
${ }^{54}$ Even if the pintura is considered lost, the relación exists in the AGI, Indiferente general, 1929, $\mathrm{n}^{\circ}$ 380. The Relaciones of Iztapalapa and Culhuacan are deposited, on the other hand, at UTX, JGI XXIII-8, mapa 7 and JGI XXIII-14, mapa 8, respectively.

${ }^{55}$ George Kubler, "On the Colonial Extinction of the Motifs of Pre-Columbian Art", in Essays in Pre-Columbian Art and Archaeology, eds. Samuel K. Lothrop and Jay I. Kislak (Cambridge (Mass.): Harvard University Press, 1961), 14-34. Bailey's work on the Texupa pintura was the first to aply Kubler's criteria to the analysis of a pintura of the Relaciones. J. W. Bailey, "Map of Texúpa (Oaxaca, 1579)", 460.
} 
from Mexicaltzingo, but that is to be found also in many others like Epazoyuca, Atlatlahuca and Suchiaca among others. ${ }^{56}$

The fifth and last criterion identifies the presence of fragments of isolated forms from the pre-Hispanic tradition that repeat themselves, but are expropriated from their previous meaning, as the forms of hills in pinturas such as the Mizantla. ${ }^{57}$ The fossilization bias of Kubler's stylistic taxonomy may be partly compensated if combined with the detailed analysis of each of the native pinturas as Leibsohn suggested for the codices she called "cartographic histories", 58 where the four main pre-Hispanic conventions are, in greater or lesser degree, made visible in the ways of territorial representation, both symbolic and geographic. ${ }^{59}$ The main conventions are seen in the use of glyphs to draw names of people, places, and dates; the use of margin outlines, but no frames; the drawing of bodies following the "Aztec proportion"; and, finally, the absence of shadow lines depicting the ground.

It is not possible to address each one of these elements here, especially because a satisfactory analysis of the tlaquiloque in the Relaciones is yet to be done and will, evidently, require contributions from a multidisciplinary team.

\footnotetext{
${ }^{56}$ Ana Elsa Chávez et. al., "Pintura de Atlatlahuca, 1588: un análisis espacial”, in Mapas de la mitad del mundo. La cartografía y la construcción territorial de los espacios americanos. Siglos XVI al XIX, coords. Francisco Roque de Oliveira and Héctor Mendoza Vargas, (LisboaMéxico: Universidad de Lisboa - UNAM - Instituto de Geografía, 2012), 131-148. The pintura analysed by the authors is not, in reality, part of the Relación, although it is practically coeval and preceding from a petition of land ownership. It may be found in AGN, Tierras.

${ }^{57}$ Karl W. Butzer and Barbara J. Williams, "Three indigenous maps from New Spain dated ca.1580", Annals of the Association of American Geographers, 82 (1992): 522-542. The authors selected the pintura of Misantla (together with Cempoala and Misquiahuala) for an analysis that spawned a critical diatribe with previous interpretations in Anglo-Saxon literature that treated the pinturas from a Eurocentric history of cartography.

58 Dana Leibsohn, "Primers for Memory: Cartographic Histories and Nahua Identity", in Writing Without Words. Alternative Literacies in Mesoamerica \& the Andes, eds. Elizabeth Hill Boone and Walter D. Mignolo (Durham: Duke University Press, 1994), 161-187, 164 166. Leibsohn establishes a distinction where the key element is the phrase "these painting are distinctive because of their express interest in history and the links they retain with preHispanic visual records". Ibid., 166 (emphasis added). According to her there are different cases. All the 'centenares' of maps painted by indigenous, between 1570 and 1630, with occasion of visits, land distribution, limit disputes and descriptions sent to the authorities annexed to written documents (which includes the case of the Relaciones, even if it is not explicitly mentioned) are not her object of analysis. The pinturas that are not exactly 'cartographic histories' according to the classical census by Glass (1976(b)) are conserved, eighty-seven from the regions of Oaxaca, Puebla and Veracruz. However, from our point of view, this division is not clear since some of the pinturas share elements of the cartographic histories: for example, the ones from Macuilsuchil, Misquauhala, Texupan, and, noticeably, Teozacoalco, because not all of them have toponymic glyphs or use spatial projections in the same pintura.

${ }^{59}$ Alicia M. Barabas coord., Diálogos con el territorio: simbolizaciones sobre el espacio en las culturas indígenas de México (México: Instituto Nacional de Antropología e Historia, 2003).
} 


\section{Conclusion}

We have shown how the complex colonial reality transformed the imperial project of Phillip II in its cosmographical characteristics. The conquest of a new continent was, more than anything else, associated with the ecumenical responsibilities of Spanish imperial ideology. ${ }^{60}$ We have also highlighted how the source of the colonial enterprise encoding, the Crown, via the figure of López de Velasco, systematized the desirable ways to gather knowledge from American regions under its rule. The pinturas of the Relaciones were planned out as the last chapter of the cosmography of the Indies, a vast initiative that aimed to follow the cartographical premises of Ptolemy's Geographia, from universal representations to chorographical paintings. The pinturas were the last stage of Indian cartography, the definite evidence of the discoveries. This decisive step in the dominion and control at a distance of the American reality required images to help narrate Indian nature, small frescoes to frame local knowledge of this new territoriality.

Now, were the pinturas able to comply with the demands and interests of the Council of the Indies? Were the maps of the Relaciones that arrived to Spain those that one expected to behold? López de Velasco didn't seem to think so. And the Crown also attributed little significance to the Relaciones once they arrived in the peninsula. This indicates that the pinturas did not match the requirements of the metropolis. Why was the Crown's plan to produce chorographic maps of the Indies according to Ptolemaic models not satisfied by the pinturas? Where and when was a divide produced between these two different forms of imagining and representing the American reality, of conceiving the territory, between those that are the descendants of these lands and those who want to possess it? While the Council of the Indies considered the receivers of the questionnaires as mere passive mediation inside the imperial apparatus, with no decision power or agency, the reality on the other side of the ocean was very different. The tlacuiloque took the opportunity given to them by their new lords to reassert their sense of community and reinvent their own version of a 'New Spain'. The distance between metropolis and colony provided the rest.

There is no doubt that the Relaciones indicate yet another expression of the global conscience of the Hispanic monarchy. An empire should be able to dispose of rigorous geographical and statistical knowledge, and, logically, the Crown should conceive questionnaires as the best plan to fulfil their political, economic, and evangelizing mission. ${ }^{61}$ However, the cartographic replies to

\footnotetext{
${ }^{60}$ J. Pimentel, "The Iberian Vision", 19.

${ }^{61}$ Carmelo Vias y Mey, "Las relaciones de Felipe II y su publicación”, Estudios Geográficos, 12, 42 (1951): 131-136, 135.
} 
this requirement didn't have the expected outcome. López de Velasco must have been aggravated when confronted with most of the results. Everything went very differently from what he had expected. To conceive such a project in Spain, and make it work in the hinterland of the American continent was not the same at all. Many of the compilers simply did not follow the ordered instructions. While some Relaciones did not add any pinturas, some incorporated several. Each one of the Spanish officials in New Spain had their own interpretation of what an adequate chorographic map should comprise. ${ }^{62}$ The vision Velasco had from the Iberian Peninsula was not shared by the settlers in new lands. The idea that cosmographers in the Peninsula had of the maps was not the same notion that officers in New Spain had. While the first would see these as powerful instruments to make visible the hegemony of the monarchy over distant territories, the latter would view it as yet another bureaucratic duty ordered by the Council of the Indies.

In conclusion, the Spanish monarchy acted impassively to the arrival of the reports from the Indies, and the pinturas represent an unprecedented testimony of the ideology of the imperial apparatus as reflected in its questionnaires, and, more importantly, that they testify as how this same apparatus was subject to transformations when in Amerindian lands. The pinturas offer a dissected view of a scientific and bureaucratic structure that produced an imagined representation of the New World from a utopian perspective. But they also reveal their true significance, the result of a profound gesture of affirmation from the native communities, both Spanish and creole that reinvented the new-Hispanic natural world. As effective as the questionnaires were, for the project to use knowledge gathered locally in New Spain, in order to represent distant territory surrounded in the imperial imagery of the monarchy, in the end, they resulted in a very distinct product. For the Crown the project of the Relaciones and their pinturas meant the final chapter on the cosmographical plan to appropriate the American territories, but for native populations it meant the beginning of a different period, less planned and more diffuse, a foundational act for a "New Spain".

${ }^{62}$ B. Mundy, The Mapping of New Spain, 35. 